\title{
STRATEGI ARGUMENTASI DALAM PEMBELAJARAN SEJARAH
}

\author{
Susanto Yunus Alfian, Melaningrum Andarwati, Tatik Hidayah \\ SMA Negeri 1 Sumberpucung, Kab. Malang
}

\begin{abstract}
Abstrak: Kegiatan argumentasi dapat dimanfaatkan untuk menganalisis teks sejarah. Kegiatan argumentasi pada prinsipnya menuntut siswa untuk mencari bukti-bukti yang tepat untuk mendukung klaim. Siswa memilah, memilih dan mengklasifikasi atau dengan kata lain siswa melakukan analisis. Permasalahan yang diajukan untuk dalam penelitian ini adalah bagaimanakah strategi argumentasi dilaksanakan dalam pembelajaran Kompetensi Dasar 3.11 pada Kurikulum 2013 "Menganalisis perjuangan Bangsa Indonesia dalam upaya mempertahankan kemerdekaan dari ancaman Sekutu dan Belanda" Penelitian ini menggunakan rancangan lesson study. Siklus lesson study ini meliputi plan, do dan See. Open class untuk lesson study ini dilaksanakan di kelas XIIPA2 di SMA Negeri 1 Sumberpucung Kabupaten Malang. Siswa diajak melakukan argumentasi sebagai representasi analisis teks sejarah. Pengajaran pada siklus I dilakukan pada tanggal 9 April 2015 dan siklus II pada tanggal 16 April 2015. Pada siklus I strategi pembelajaran argumentasi dilaksanakan dengan kurang maksimal. Seharusnya hasil pekerjaan siswa berupa argumen yang berisi klaim dan bukti-bukti pendukung. Pada siklus II ini, setelah ada perbaikan, strategi pembelajaran argumentasi bisa dilaksanakan secara maksimal. Perbaikannya berkenaan dengan penulisan klam di papan tulis. Guru sendiri menuliskan klaim di papan tulis.
\end{abstract}

Kata-kata kunci: Lesson study, strategi pembelajaran argumentasi, siklus.

\begin{abstract}
Argumentation activities can be used to analyze historical text. The argumentation activities in principle require students to look for appropriate evidence to support the claim. Students sorting, selecting and classifying or in other words the students do the analysis. The problem proposed for this research is how the argument strategy is implemented in learning Basic Competence 3.11 in Curriculum 2013 "Analyzing the struggle of the Indonesian Nation in the effort to defend the independence from Allied and Dutch threats" This research uses lesson study design. This lesson study cycle includes plan, do and See. Open class for lesson study was conducted in class XI-IPA2 in SMA Negeri 1 Sumberpucung, Malang. Students are invited to argue as a representation of historical text analysis. Teaching on the first cycle was conducted on April 9, 2015 and cycle II on April 16, 2015. In cycle I strategy lesson argumentation implemented with less maximum. The student's work should be an argument that contains the claim and supporting evidence. In this second cycle, after the improvement, the argumentation learning strategy can be implemented maximally. Improvements related to the writing of klam on the board. Teacher himself writes a claim on the board.
\end{abstract}

Keywords: lesson study, argumentation teaching strategy, cycles

Dalam sejarah, causal arguments merupakan bagian dari ekplanasi sejarah (Lichtman \& French, 1978). Argumentasi dalam hal ini menjadi penting karena merupakan hal yang mendasar dalam alasan sejarah (van Drie \& van Boxtel, 2008). Sejarawan melakukan alasan sejarah untuk menghasilkan suatu pendapat atau pandangan yang harus didukung dengan argumen dan bukti (van Drie \& van Boxtel, 2008). Sejarawan membuat kesimpulan dan itu tidak berarti kepastian. Kesimpulan adalah sementara. Bila ada bukti baru, kemungkinan kesimpulan yang telah ada juga bisa berubah. 
Argumentasi sebagai strategi pembelajaran telah diteliti pengaruhnya pada pembelajaran. Proses argumentasi dengan membuat klaim dan alasannya dapat meningkatkan perubahan konseptual pada siswa (Eskin \& Ogan-Bekiroglu, 2013). Kelompok eksperimen diberi kegiatankegiatan yang mengarahkan siswa untuk berargumentasi seperti membuat klaim dan alasannya dibalik pilihan yang ditentukannya. Sebaliknya kelompok kontrol tidak diberi kegiatan berargumentasi seperti memilih jawaban dari pilihan ganda yang ada. Baik kelompok eksperimen ataupun kelompok kontrol beberja dalam kelompok. Setelah bekerja dalam kelompok, kelompok eksperimen menyajikan gagasannya di depan diskusi kelas. Sebaliknya kelompok kontrol menuliskan jawabannya di kertas jawaban. Hasilnya menunjukkan bahwa kelompok eksperimen dapat meningkatkan perolehan perubahan konseptual lebih banyak dari pada kelompok kontrol.

Argumentasi bukanlah bentuk lain dari alasan, tetapi argumentasi merupakan kegiatan yang melibatkan alasan (Schwarz \& Asterhan dalam Littleton et al, 2008). Argumentasi juga sebagai persuasi. Argumentasi tidak menggunakan aturan logika formal tapi lebih merupakan suatu kegiatan alasan informal. Ketika sedang melakukan kegiatan berargumentasi, hasilnya adalah argumen mana yang bisa diterima atau yang tidak bisa diterima.

Menurut Toulmin (Leitao, 2000), ada enam konsep berkenaan dengan argument. (1) Claim (pendapat atau kesimpulan dengan harapan agar diterima oleh pihak lain). (2) Grounds atau Data (fakta atau opini yang menjadi dasar suatu claim) contoh: Presiden Sukarno dilahirkan di Blitar. (3) Warrant (berupa rumus atau prinsip pernyataan umum yang mengantarkan dari data ke claim). Warrant merupakan general statements atau hypothetical statements (Verheij, 2005). (4) Backing (informasi yang mendukung atau memperkuat warrant). Verheij (2005) mengartikan backing sebagai statements of fact, contoh: statuta, undang-undang, dan laporan statistik. (5) Qualifier (pemberian kemungkinan penguat terhadap tingkat kepastian kesimpulan misal dengan menggunakan kata keterangan certainly, presumably, probably, possibly). Rebuttal (kondisi yang mendasari argumen atau kondisi yang melemahkan argumen). Berland \& McNeil (2010) membuat model argumen sederhana yaitu terdiri dari bukti dan claim.

Kita harus membedakan antara hasil belajar dan kegiatan belajar yang digunakan untuk memperoleh hasil tersebut (Anderson \& Krathwohl, 2001). Kemampuan argumenatif bisa menjadi hasil belajar yang ingin dicapai oleh siswa, setelah mereka melalui belajar. Argumen sebagai produk berupa sebuah wacana sebaga hasil penalaran yang men-justify suatu claim (Berland \& McNeill, 2009). Namun demikian disamping sebagai hasil belajar, melakukan kegiatan argumentasi bisa juga menjadi kegiatan untuk mencapai tujuan belajar. Jadi kemampuan argumenatif sebagai hasil belajar dan kegiatan argumenatif sebagai aktifitas belajar harus dibedakan.

Sebagai aktifitas belajar, siswa yang melakukan kegiatan menulis argumen dari berbagai sumber sejarah bisa memperoleh hasil pemahaman suatu topik sejarah lebih baik (Kuhn \& Udell, 2003) dibandingkan dengan kegiatan membuat narasi (Wiley \& Voss, 1999). Dengan kegiatan pembuatan argumen, siswa bisa membangun suatu representasi isi bacaan. Atau dengan kata lain, siswa bisa membangun suatu model situasi terhadap teks yang dibaca. Ketika siswa membuat suatu argumen, mereka melakukan transformasi dari teks ke dalam argumen yang mereka buat. Sehingga siswa 
tidak hanya sekedar menceritakan kembali seperti pada kegiatan membuat narasi. Kegiatan menulis argumen bisa merupakan kegiatan pembelajaran dan menunjukkan hasil yang lebih baik dibanding kegiatan menulis narasi. Kegiatan menulis argumen termasuk knowledge transforming, sedangkan kegiatan menulis narasi termasuk knowledge telling. Kegiatan menulis argumen sebagai knowledge transforming adalah lebih baik dari knowledge telling dalam hal pemahaman. Karena dengan menulis argumen, siswa bisa mendapat pemahaman konseptual dan kausal lebih banyak. Sebaliknya knowledge telling adalah hanya lebih unggul dalam hal pengungkapan kembali kalimat-kalimat yang telah dibaca. Jadi kegiatan menulis argumen itu bisa meningkatkan (1) pemahaman kausal suatu pelajaran, (2) pemahaman konseptual pelajaran, dan (3) hasil tulisan yang "more transformed, integrated \& causal". Argumentasi yang dibuat seseorang terhadap suatu merupakan representasi pengetahuan seseorang terhadap sesuatu tersebut (Munford \& Zembal-Saul, 2002).

Kami beranggapan bahwa kegiatan argumentasi dapat dimanfaatkan untuk menganalisis teks sejarah. Kegiatan argumentasi pada prinsipnya menuntut siswa untuk mencari bukti-bukti yang tepat untuk mendukung klaim. Mencari bukti dalam konteks ini berarti siswa memilah dan memilih informasi yang sesuai. Kegiatan memilah dan memilih itu merupakan kegiatan menganalisis. Jadi argumentasi menjadi kegiatan yang merepresentasikan kegiatan menganalisis.

Sebagai refleksi dari konteks teoritis dan konteks di lapangan tersebut, penulis berkeyakinan untuk melakukan lesson study di kelas yang saya ajar. Lesson study itu dilakukan dalam rangka untuk memperbaiki praktek pembelajaran yang telah berlangsung selama ini. Dalam penelitian ini praktek pembelajaran yang menggunakan strategi pembelajaran argumentasi yang kami lakukan ditujukan untuk mengajarkan analisis kepada siswa. Dengan kata lain lesson study ini digunakan sebagai salah satu upaya untuk mengembangkan profesionalisme kami sebagai guru matapelajaran Sejarah Indonesia. Untuk itu, permasalahan yang diselesaikan adalah bagaimanakah strategi pembelajaran argumentasi dilaksanakan sebagai bentuk pembelajaran Kompetensi Dasar 3. 11 pada Kurikulum 2013 yang berbunyi "Menganalisis perjuangan Bangsa Indonesia dalam upaya mempertahankan kemerdekaan dari ancaman Sekutu dan Belanda"?

\section{METODE}

\section{Rancangan Lesson study}

Penelitian ini menggunakan rancangan lesson study. Lesson study adalah suatu bentuk pengembangan profesional guru yang dilakukan secara kolaboratif melalui siklus berkelanjutan (Takahashi \& Yoshida, 2004: Cerbin \& Kopp, 2006; Post \& Varoz, 2008). Siklus tersebut diadaptasi dan meliputi kegiatan-kegiatan sebagai berikut: plan (membuat tujuan dan merancang rencana pengajaran), $d o$ (mengajarkan pelajaran yang telah dirancang dan mengamati pelajaran yang telah dirancang tersebut), dan see (mendiskusikan, merefleksi dan merevisi pelajaran yang didasarkan pada proses belajar siswa).

Open class untuk lesson study ini dilaksanakan di kelas XI-IPA2 di SMA Negeri 1 Sumberpucung Kabupaten Malang. Siswa di kelas ini berjumlah 28 orang. Seperti kelas-kelas lainnya, siswa di kelas ini telah dipilih secara acak sejak masuk kelas X.

Waktu pelaksanaan penelitian ini dilaksanakan pada semester dua bulan 
Maret dan April tahun pelajaran 2014-2015. Tempat pelaksanaan penelitian ini adalah di kelas XI-IPS 2 SMA Negeri 1 Sumberpucung Kab. Malang. Pengajaran pada siklus I dilakukan pada tanggal 9 April 2015 dan pada siklus II dilakukan pada tanggal 16 April 2015.

Tim lesson study ini terdiri dari tiga orang guru. Pada prinsipnya tim bisa beranggota dua orang atau lebih (Lewis \& Tsuchida, 1998). Guru sejarah Indonesia terdiri dari dua orang dan satu orang guru biologi. Susanto Yunus Afian (guru sejarah) di kelas yang digunakan sebagai open class dalam lesson study ini bertindak sebagai guru model. Melaningrum Andarwati sebagai anggota kedua dalam tim mengajar matapelajaran Sejarah kelas XII dan tatik Hidayah sebagai anggota ketiga mengajar matapelajaran Biologi di kelas XII-IPA. Jadi tim lesson study ini termasuk kategori tim interdisipliner.

Kompetensi dasar (KD) yang diajarkan dalam lesson study ini adalah KD 3. 11 yang berbunyi "Menganalisis perjuangan Bangsa Indonesia dalam upaya mempertahankan kemerdekaan dari ancaman Sekutu dan Belanda. Kompetensi dasar ini tercantum dalam Permendikbud nomor 69 Tahun 2013 tentang Kerangka Dasar Dan Struktur Kurikulum Sekolah Menengah Atas/Madrasah Aliyah.

Materi pelajaran yang digunakan adalah Perubahan dan perkembangan politik masa awal kemerdekaan. Materi pelajaran ini terdapat di Buku Sejarah Indonesia kelas XI Semester 2. Buku ini diterbitkan oleh Departemen Pendidikan dan Kebudayaan tahun 2014.

\section{Tahapan Lesson study}

Penelitian ini merupakan lesson study yang terdiri dari dua siklus. Setiap siklusnya terdiri dari kegiatan-kegiatan, tahap-tahap atau fase-fase: plan, do dan See. Tahap-tahap itu diuraikan dibawah ini: 1. Plan
Pada tahap plan, tim mengadakan penentuan fokus lesson study dan perencanaan pengajaran.Untuk menentukan fokus okus Lesson study, peneliti dan satu orang guru sejarah lain menentukan tema atau fokus serta satu orang guru lagi yang tidak mengajar sejarah. Fokus yang akan diperbaiki merupakan research theme, important aim atau long term goal (Lewis, 2002). Fokus lesson study ini tidak diarahkan pada fokus what students learn tapi pada how students learng from the lesson (Cerbin \& Kopp, 2006). Sehingga fokusnya terletak pada student thinking yaitu bagaimana siswa belajar berargumentasi. Lesson study ini tidak meneliti keefektifan pembelajaran yang hanya membandingkan antara pretest dan posttest.

Tema lesson study diambil dari matapelajaran sejarah Indonesia kelas XI semester 2. Sesuai dengan kompetensi dasar yang menuntut siswa untuk menganalisis, kami mengajak siswa untuk menganalisis dengan melakukan argumentasi. Kompetensi dasar yang menjadi fokus adalah Kompetensi Dasar 3. 11 yang berbunyi "Menganalisis perjuangan Bangsa Indonesia dalam upaya mempertahankan kemerdekaan dari ancaman Sekutu dan Belanda." Kami perlu mendapatkan bukti tentang kegiatan siswa dalam menganalisis. Agar siswa melakukan analisis, siswa diajak untuk mencari informasi,data, peristiwa atau fakta yang menjadi pendukung terhadap klaim yang diberikan. Sehingga pemberian pelajaran yang mengajak siswa melakukan argumentasi tersebut merupakan kegiatan utama dari stategi pembelajaran argumentasi yang menjadi fokus kegiatan pada lesson study ini. Disini siswa menganalisis peristiwa sejarah. Siswa memilah, memilih dan mengelompokkan informasi, fakta atau peristiwa sejarahh yang digunakan dalam proses argumentasi. Proses argumentasi ini menghasilkan 
argumen yang berisi dua komponen yaitu klain dan bukti pendukungnya.

Untuk melakukan Perencanaan pengajaran, dari hasil berbagi pengalaman dan pengetahuan yang telah dilakukan, peneliti telah merencanakan untuk melakukan strategi pembelajaran argumentasi sebagai pelaksanaan kompetensi dasar menganalisis di kelas. Tim mendiskusikan pelajaran yang dikembangkan secara bersama. Masingmasing anggota tim saling berbagi tentang pengalaman mengajarkan materi yang akan di-lesson study-kan. Kami mengantisipasi pertanyaan-pertanyaan yang mungkin muncul dari siswa dan kemungkinan jawaban yang harus diberikan oleh guru. Hasil dari tahap ini adalah rencana pengajaran yang akan secara terbuka dilaksanakan dan diamati secara bersama. Pelajaran yang dilaksanakan dan diamati ini bernama research lesson (Lewis, Perry, \& Murata, 2006). Argumentasi siswa merupakan bentuk pelaksanaan kompetensi dasar menganalisis yang bisa diamati. Dengan begitu, student thinking bisa menjadi visible (Cerbin \& Kopp, 2006).

\section{Do}

Pada tahap ini, peneliti melakukan tindakan pembelajaran seperti yang telah dirancang dan tertulis pada rencana pelaksanaan pembelajaran dan dua guru lain melakukan pengamatan. Tindakan yang dilakukan berupa strategi pembelajaran argumentasi. Sedangkan anggota lainnya melakukan pengamatan. Anggota lain tersebut adalah Dra. Melaningrum Andarwati (guru sejarah) dan Hj. Tatik Hidayah, SPd (guru biologi). Mereka mengamati keterlaksanaan, mengamati hasil pekerjaan siswa dan mewancarai siswa untuk mengklarifikasi proses yang dilakukan siswa. Data tersebut berkenaan dengan permasalahan yang dihadapi siswa dan pemahaman yang salah yang dilakukan oleh siswa (Stepanek et al, 2006)
3. See

Pada tahap SEE, tim melakukan diskusi dan refleksi. Setelah mengajarkan pelajaran, tim lesson study bertemu untuk mendiskusikan hasil pengamatan. Anggota tim mengkritisi pelaksanaan pembelajaran. Tim mendalami bukti-bukti yang berkaitan dengan pelajaran yang telah diajarkan. Tim menganalisis bukti-bukti tersebut.

Anggota tim lesson study saling berbagi pendapat tentang hasil pengamatan yang telah dilakukan. Tahap ini merupakan kegiatan merefleksi tindakan pembelajaran yang telah dilakukan. Kami mempertimbangkannya sebagai bahan untuk merevisi atau perencanaan ulang tindakan pengajaran berikutnya. Yang direfleksi merupakan hasil tindakan. Hasil refleksi ditujukan sebagai pertimbangan utama untuk melakukan perencanaan siklus berikutnya.

Setelah mendiskusikan hasil, tim lesson study bertemu lagi untuk membuat perubahan-perubahan atau perbaikanperbaikan pelajaran. Berdasarkan buktibukti yang telah disampaikan, tim lessons tudy mengadakan revisi-revisi terhadap pendekatan yang telah digunakan. Perubahan dan perbaikan itu dituangkand alam bentuk rencana pengajaran perbaikan yang diulang lagi pada siklus berikutnya.

\section{Pengumpulan Data dan Analisis Data}

Data yang dikumpulkan berupa pekerjaan siswa (students' work). Siswa melakukan argumentasi. Setelah klaim dibuat, siswa mencari bukti-bukti atau informasi untuk mendukung klaim tersebut. Bukti atau informasi tersebut dirangkai secara urut waktu atau sekuensial. Rangkaian bukti atau informasi itu menjadi alasan. Alasan yang ditulis oleh siswa itu merupakan data pengalaman belajar siswa. Alasan itu menjadi pekerjaan siswa yang ditulis di buku tulis.

Alasan tersebut dianalisis dengan kriteria kesesuaian antara klaim dan bukti 
yang telah tersedia di buku teks Sejarah Indonesia kelas XI. Jika bukti atau informasi yang diberikan tidak sesuai atau tidak mendukung klaim, maka alasan tersebut tidak memenuhi kriteria sebagai alasan yang bisa mendukung klaim. Ketidak sesuaian itu menggambarkan bahwa student thinking perlu dibenahi melalui revisi dan modifikasi pelajaran.

Pada saat pengamatan, dua anggota tim melakukan pengamatan terhadap tindakan yang dilakukan. Pengamatan dilakukan dalam rangka untuk mengumpulkan informasi yang berasal dari tiga sumber. Sumber pertama adalah pekerjaan siswa. Sumber kedua adalah lembar pengamatan keterlaksanaan rencana pengajaran. Dan sumber terakhir adalah wawancara.

Data dari sumber pertama diambil dari hasil pekerjaan siswa. Pengamatan siswa diarahkan pada hasil pekerjaan siswa yang berupa tulisan terhadap hasil argumentasinya. Anggota tim mengambil sampel pekerjaan 12 siswa dari empat topik. Untuk setiap topik, diambil tiga siswa. Data dari sumber kedua diambil dari lembar pengamatan keterlaksanaan pembelajaran. Pelaksanaan pembelajaran dilakukan oleh guru dengan mengikuti langkah-langkah pembelejaran. Langkah-langkah pembelajaran itu terlihat dari sintaks yang terdapat di rencana pelaksanaan pembelajaran. Guru memberi tanda centang di rencana pengajaran untuk langkahlangkah yang telah dilaksanakan. Kemudian diprosentasi. Caranya adalah bahwa jumlah yang terlaksana dibagi lima. Hasil pembagian itu dikalikan 100, sehingga hasil akhir berupa prosentasi keterlaksanaan.

Sintaksnya terdiri dari lima langkah sebagai berikut. Guru mengorientasikan peserta didik terhadap masalah. Guru mengorganisasi peserta didik untuk belajar. Guru membimbing penyelidikan individual maupun kelompok. Siswa mengembangkan dan menyajikan hasil karya. Dan terakhir guru menganalisis dan mengevaluasi proses pemecahan masalah

Data pengamatan ketiga diambil dari wawancara. Wawancara dilakukan di beberapa kelompok. Wawancara dilakukan untuk mahami pemikiran siswa tentang informasi atau bukti yang dijadikan alasan dalam berargumentasi. Wawancara itu digunakan untuk mengklarifikasi hasil dan proses pekerjaan siswa.

\section{HASIL DAN PEMBAHASAN}

\section{Siklus I}

1. Plan

Pada tahap plan ini, tim melakukan dua kegiatan yaitu penentuan fokus lesson study dan perencanaan pengajaran. Pada kegiatan penentuan fokus lesson study, kami memulai lesson study dengan melihat buku teks Sejarah Indonesia kelas XI. Buku ini diterbitkan oleh Departemen Pendidikan. Penerbitan buku ini merupakan buku wajib dalam melengkapi pelaksanaan kurikulum 2013. Isi atau topik dalam buku ini merupakan uraian atau cerita sejarah yang disesuaikan dengan kompetensi dasar yang telah dikeluarkan oleh Kementerian pendidikan tahun 2013.

Selain mendalami buku teks, tim juga mengkaji kompetensi dasar. Kami ingin menjembatani antara yang diinginkan di kompetensi dasar dengan kenyataan di lapangan. Kompetensi dasar 3. 11 berbunyi "menganalisis perjuangan bangsa Indonesia dalam upaya mempertahankan kemerdekaan dari ancaman Sekutu dan Belanda."

Kami memadukan antara yang ada di buku teks dan yang diminta oleh kompetensi dasar. Topik-topik atau cerita yang ada di buku teks harus dipahami oleh siswa. Untuk memahami tersebut, siswa harus menganalisisnya yang tentu saja sesuai dengan yang dituntut oleh 
kompetensi dasar. Untuk melakukan analisis, siswa diajak untuk melakukan pemilihan bukti atau informasi yang semua itu merupakan pembuatan alasan untuk mendukung klaim yang diberikan. Kegiatan pembelajaran seperti itu merupakan strategi pembelajaran argumentasi.

Pada kegiatan perencanaan pengajaran, setelah membahas kompetensi dasar dan menentukan strategi pembelajaran, tim melakukan perencanaan pengajaran. Rencana pengajaran telah dibuat. Rencana pengajaran yang telah dicetak dibaca, dianalisis dan dibenahi bila ada yang kurang disepakati. Namun demikian seluruh anggota tim sepakat dan siap melaksanakan.

Materi pelajaran yang diajarkan yang terdapat di rencana pengajaran pada Siklus I adalah topik: perjanjian Linggarjati. Topik ini terdiri dari empat sub topik yaitu: perundingan awal di Jakarta, perundingan Hooge Veluwe, pelaksanaan perundingan Linggarjati, dan konferensi Malino. Semua materi pada empat sub topik tersebut terdapat pada buku Sejarah Indonesia kelas XI.

Kegiatan pembelajaran yang terdapat pada rencana pengajaran pada siklus I ini adalah kegiatan pembelajaran argumentasi. Sebagai strategi pembelajaran argumentasi, kegiatannya dilakukan sebagai berikut. Pertama, siswa dibagi dalam kelompokkelompok yang terdiri dari empat siswa. Pembagian dini didasarkan pada jumlah sub topik yang terdiri dari empat sub topik. Anggota kesatu mendalami subtopik perundingan awal di Jakarta. Anggota kedua mendalami subtopik perundingan Hooge Veluwe. Anggota ketiga mendalami pelaksanaan perundingan Linggarjati. Dan anggota keempat mendalami subtopik konferensi Malino.

Setelah pembagian kelompok dan penentuan tugasnya dilakukan, maereka semua diajak untuk merubah subtopik yang masih berupa judul (kata benda) ke bentuk klaim (kalimat pernyataan). Sehingga juduljudul subtopik tersebut yang telah dijadikan klaim berbentuk seperti berikut:

1. Belanda dan Indonesia melakukan perundingan awal di jakarta.

2. Perundingan Hooge Veluwe mengalami kegagalan

3. Indonesia dan Belanda mengadakan perundingan Linggarjati

4. Belanda mengadakan konferensi Malino

Begitu klaim telah dibuat seperti diatas, tugas siswa adalah pencarian buktibukti/informasi di buku teks yang mendukung klaim tersebut. Bukti-bukti atau informasi yang tidak mendukung tidak perlu dituliskan sebagai alasan untuk mendukung klaim. Jadi siswa hanya mencari yang sangat sesuai saja dan logis mendukung klaim tersebut.

2. Do

Pada tahap DO ini, penulis melakukan pengajaran dan dua orang anggota lainnyha melakukan pengamatan. Saya (penulis) bertugas untuk mengajarkan pelajaran. Rencana pengajaran yang kami buat bersama dilaksanakan di kelas XIIPS2. Waktu untuk mengajarkan itu adalah hari Kamis tanggal 9 April 2015 pada jam ke 3-4. Saya berusaha mengikuti strategi dan sintaks yang ada di rencana pengajaran

Pada saat guru model mengajarkan pelajaran, dua orang observer melakukan pengamatan keterlaksanaan rencana pengajaran dan mendokumentasikan kegiatan pembelajaran dengan kamera video. Diluas kelas kami bertiga mengamati lagi hasil pekerjaan siswa.

3. See

Semua anggota berkesempatan untuk menyampaikan hasil pengamatannya dalam suatu diskusi. Guru model menyampaikan pendapat saya tentang pelajaran yang telah saya ajarkan. Guru model menyampaikan permasalahan atau kesulitan yang saya 
alami selama tahap pengajaran. Disamping menyampaikan kesulitan tersebut, guru model juga menyampaikan hal-hal yang ingin saya diskusikanh dengan dua anggota teresebut. Setelah uru model menyampaikan pendapat, dua orang observer saling bergiliran untuk menyampaikan pendapatnya berdasarkan data pengamatan.

Semua pendapat difokuskan pada keterlaksanaan rencana pengajaran yang telah disajikan dan kegiatan siswa dalam belajar. Diskusi diarahkan pada tujuan atau tema atau fokus lesson study yang telah ditentukan. Diskusi dimaksudkan untuk mendapatkan gambaran tentang bagaimana siswa memahami dan mempelajarai pelajaran yang diberikan yaitu melakukan argumentasi dengan membentuk alasanalasan. Jadi diskusi difokuskan pada pelajaran yang telah disajikan.

Pada siklus I strategi pembelajaran argumentasi dilaksanakan dengan kurang maksimal. Seharusnya hasil pekerjaan siswa berupa argumen yang berisi klaim dan bukti-bukti pendukung. Akan tetapi masih ada beberapa siswa yang hanya menuliskan bukti-bukti atau informasi pendukungnya saja dan tidak menuliskan klaimnya. Hal itu dikarenakan oleh dua alasan berikut. Pertama adalah bahwa siswa menganggap bahwa guru hanya menginginkan buktibukti atau informasi pendukungnya saja. Kedua adalah bahwa ada siswa tidak mengetahui jika suatu argumen itu terdiri dari klaim dan bukti pendukungnya.

\section{Siklus II}

\section{Plan}

Ada dua perbaikan dalam perencanaan pada siklus II ini. Pertama adalah tentang perlunya menuliskan semua klaim di papan tulis. Kedua adalah tentang perlunya mempresentasikan hasil kerja masing-masing di depan kelas.

Pada siklus II ini, klaim dituliskan di papan tulis. Empat judul subtopik dituliskan di papan tulis dan ditransformasikan kedalam bentuk klaim. Empat klaim yang dituliskan di papan tulis adalah sebagai berikut: Agresi militer Belanda I, Komisi Tiga Negara, Perjanjian Renville dan Agresi militer Belanda II. Dan keempat judul subtopik tersebut dirubah dalam bentuk klaim seperti berikut: Belanda melakukan Agresi militer I, Komisi Tiga Negara bertugas sebagai mediator, Perjanjian Renville diadakan, dan Belanda melakukan Agresi Militer II.

Pada siklus II ini juga, setiap klaim dan hasil pekerjaan siswa yang mendukung klaim dipresentasikan di depan kelas. Tiga orang dipilih secara acak untuk menampilkannya. Dengan demikian ada 12 siswa yang tampil di depan kelas.

$$
\text { 2. Do }
$$

Pada siklus II, pengajaran dilakukan sesuai dengan rencana pengajaran yang telah direvisi. Tindakannya masih tetap seperti pada siklus I yaitu strategi pembelajaran argumentasi. Sedangkan perbaikan atau modifikasinya adalah sebagai berikut: guru model menuliskan semua klaim di papan tulis dan meminta siswa untuk mempresentasikan hasil kerjanya di depan kelas. Dalam hal ini guru model memilih siswa secara acak dimana tiap subtopik diwakili oleh dua orang siswa.

Pembagian tugas anggota tim masih melanjutkan seperti pada siklus I. Dengan kata lain, pada siklus II ini saya bertindak sebagai guru pengajar atau guru model dan dua orang observer bertindak sebagai pengamat. Komposisi tim dan tugas masing-masing anggota tim antara siklus I dan siklus II tidak mengalami perubahan.

Dua anggota tim diberi tugas pengamatan yang lebih jelas. Tatik Hidayah mencari beberapa contoh tentang bagaimana siswa mengkonstruksi pemahamannya. Melaningrum Andarwati mencatat berbagai macam cara yang digunakan oleh siswa dalam menyelesaikan 
tugas atau kesalahan yang dibuat. Mereka berkeliling di sela-selah bangku siswa dalam rangka pengamatan.

\section{See}

Kami mediskusikan dan merefleksi hasil pengamatan. Tata cara diskusi diatur seperti berikut. Pertama, guru model memaparkan acara diskusi (2 menit). Kedua, guru model memaparkan tujuan lesson study (5 menit). Ketiga, agar anggota secara aktif memberi masukan atau umpan balik, guru model memberi ketentuan seperti berikut: ketika salah satu peseta diskusi menyampaikan pendapatnya, orang lain tidak boleh menyela; setiap orang berpeluang sama untuk menyampaikan pendapatnya; semua memberi bukti dan bukan opini. Dan terakhir, guru model sebagai pengajar memberi pendapat tentang pelajaran yang telah diajarkan. Guru model menyampaikan hal-hal yang terjadi selama pengajaran (apa yang berjalan baik, apa yang kurang berjalan baik).

Diskusi diusahakan saling menghargai. Semua anggota memberi pendapat tentang aspek-aspek positif pelajaran. Semua mengkritisi pelajaran dan tidak mengkritisi pribadi guru pengajar. Kita tidak menekankan pada keberhasilan atau kegagalan pelajaran ataupun gaya mengajar. Semua berpartisipasi aktif dalam diskusi.

Hasil diskusi dapat disimpulkan sebagai berikut. Penulisan klaim di papan tulis diikuti dengan tepat oleh siswa sebagai satu komponen argumen yang diperlukan. Sehingga hasil pekerjaan siswa berupa argumen yang telah memiliki dua unsur minimal sebagai argumen yaitu klaim dan bukti pendukung. Disamping penulisan klaim tersebut, presentasi hasil pekerjaan siswa di depan kelas akan secara tidak langsung memberi bantuan untuk memperbaiki pekerjaannya.

Pada siklus II ini, setelah ada perbaikan, strategi pembelajaran argumentasi bisa dilaksanakan secara maksimal. Perbaikannya berkenaan dengan penulisan klam di papan tulis. Guru sendiri menuliskan klaim di papan tulis. Empat judul topik pada pengajaran siklus II ini diubah kedalam klaim. Setiap topik diubah kedalam klaimnya. Pencamtuman klaim ini membantu siswa dalam proses belajarnya. Dalam kegiatan memproduksi argumen, siswa bisa dengan mudah membuat argumen dengan lengkap. Dua unsur argumen menjadi bisa ditulis oleh siswa. Dua unsur tersebut adalah klaim dan bukti. Jika argumen disajikan secara tertulis, kedua unsur tersebut harus ada. Dengan demikian tulisan siswa memenuhi syarat sebagai argumen.

Kegiatan argumentasi ini digunakan sebagai wujud dari menganalisis teks sejarah. Hasil argumentasi ini difungsikan sebagai cerita terhadap topik yang dianalisis. Siswa harus memilah dan memilih bukti-bukti/fakta-fakta/informasi yang tepat untuk mendukung klaim. Jika klaimnya ditulis dan bukti pendukungnya juga ditulis, maka cerita yang disajikan akan lengkap. Dengan demikian ceritanya akan bersifat koherens sebagai cerita yang bersifat argumentatif. Tentu saja pencantuman klaim tersebut akan mengarahkan siswa untuk memilih dan memilih bukti-bukti pendukungnya.

\section{KESIMPULAN}

Pada siklus I, ada beberapa kelemahan di perencanaan yang berpengaruh pada kurang maksimalnya di pelaksanaan pengajaran. Pada prinsipnya, siswa harus menuliskan klaim dan buktibukti atau informasi pendukung. Akan tetapai beberapa siswa tidak menuliskan klaimnya. Dengan kata lain mereka hanya menuliskan bukti-bukti atau informasi pendukungnya saja. Pada hal, mereka harus melakukan argumentasi yang pada 
prinsipnya harus membuat klaim dan bukti pendukungnya.

Pada siklus II, tim melakukan modifikasi pengajaran di perencanaan. Jika pada siklus I, klaim tidak ditampilkan secara eksplisis di papan tulis, pada siklus II ini klaim ditulis secara nyata di papan tulis. Dengan demikian semua klaim ditulis di papan tulis. Hal ini berdampak pada argumentasi siswa yang lebih baik. Siswa melakukan argumentasi dengan lebih lengkap, karena siswa menulis klaim dan juga bukti-bukti atau informasi pendukungnya. Disamping menuliskan semua klaim di papan tulis, pada siklus II ini siswa juga mempresentasikan hasil kerjanya. Dan itu berdampak positif pada semua siswa karena mereka akan memperbaiki hasil kerjanya sesuai dengan persyaratan argumen yang baik.

\section{DAFTAR RUJUKAN}

Anderson, L. W. \& Krathwohl, D. R. 2001. A Taxonomy for Learning, Teaching and Assessing: a Revision of Bloom's Taxonomy of Educational $\mathrm{Ob}$ jectives. New York: Addison Wesley Longman, Inc.

Berland, L. K. \& McNeil, K. L. 2010. A learning progression for scientific argumenation: understanding student work and designing supportive instructional contexts. Science Education, 94 (5),: 765-793.

Cerbin, W. \& Kopp, B. 2006. Lesson study as a model for building pedagogical knowledge and improving teaching. International Journal of Teaching and Learning in Higher Education, 18 (3), 250-257.
Eskin, H. \& Ogan-Bekiroglu, F. 2013. Argumentation as a strategy for conceptual learning of dynamics. Research of Science Education, 43: 19391956.

Kuhn, D. \& Udell, W. 2003. The development of argumen skills. Child Development, 74 (5), 1245-1260.

Leitao, S. 2000. The potential of argument in knowledge building. Human Development, 43 (6): 332-360.

Lewis, C. 2002. Does lesson study have a future in the United States? Nagoya Journal of Education and Human Development, 1, $1-23$.

Lewis, C. \& Tsuchida, I. 1998. A lesson like a swftly flowing river: how research lessons improve Japanese education. American Educator, 22 (4), 12-17; 5052.

Lewis, C., Perry, R., \& Murata, A. 2006. How should research contribute to instructional improvement? The case of lesson study. Educational Researcher, 35 (3), 3-14.

Lichtman, A. J. \& French, V. 1978.Historians and the living past: the theory and practice of historical study. Arlington Heights, Ill: Harlan Davidson, Inc.

Littleton, K., Wood, C \&Staarman, J. K. 2008.Handbook of educational psychology: new perspectives on learning and teaching. Elsevier Press.

Munford, D., \& Zembal-Saul, C. 2002. Learning science trough argumentation: prospective 
teachers' experience in an innovative science course. ERIC ED 465520 - SE 066110.

Post, G., \& Varoz, S. (2008). Supporting teacher learning: lesson study groups with prospective and practicing teachers. Teaching Children Mathematics, 14 (8), 472-478.

Stepanek, J., Appel, G., Leong, M., Mangan, M. T., Mitchell, M. 2006. Leading lesson study: a practical guide for teachers and facilitators. Thousand Oaks, CA: Corwin Press.

Takahashi, A. \& Yoshida, M. 2004. Ideas for establishing lesson study communities. Teaching
Children Mathematics, 10 (9), 436-443.

Van Drie, J. \& van Boxtel, C. 2008. Historical reasoning: towards a framework for analyzing students' reasoning about the past. Educational Psychology Review, 20 (2), 87-110.

Verheij, B. 2005. Evaluating argumens based on Toulmin's scheme. Argumenation, 19, 347 - 371.

Wiley, J. \& Voss, J. F. 1999. Constructing argumens from multiple sources: tasks that promote understanding and not just memory for text. Journal of Educational Psychology, 91(2), 301-311. 